\title{
Studi Deskriptif Riwayat Menstruasi Remaja Putri Sebagai Calon Ibu Di Wilayah Pekalongan
}

\author{
Emi Nurlaela ${ }^{1}$, Dian Kartikasari ${ }^{2}$ \\ Program Studi Sarjana Keperawatan dan Pendidikan Profesi Ners \\ Fakultas Ilmu Kesehatan Universitas Muhammadiyah Pekajangan Pekalongan \\ Email: nurlaela_stikespkj@yahoo.co.id
}

\begin{abstract}
Abstrak.Remaja putri secara fisiologis akan mengalami menstruasi. Riwayat menstruasi yang dialami remaja berbeda dan dipengaruhi berbagai faktor. Penelitian ini bertujuan untuk mengetahui riwayat menstruasi yang dialami remaja putri sebagai calon ibu dari menstruasi pertama sampai akhir, sebagai identifikasi kesehatan reproduksi yang terganggu. Penelitian menggunakan kuesioner dengan jumlah responden 161 orang, teknik pengambilan sampel accidental sample. Hasil penelitian menunjukkan lebih banyak remaja akhir (19-24 tahun) sebanyak 156 orang $(96.89 \%)$. Dari 156 remaja akhir, $61(39,10 \%)$ berusia 19 tahun. Menstruasi pertama terbanyak 12 tahun sebanyak $61(37.90 \%)$, namun ada yang menarche pada 16 tahun sebanyak 3 (1.86\%) dan usia 17 tahun sebanyak 1 (0.62\%). Siklus menstruasi terbanyak 28 hari $87(54,04 \%)$ dan $74(45,96 \%)$ siklus 35 hari. Remaja lebih banyak mengalami menstruasi yang lamanya $<2$ minggu $157(97,51 \%)$. Namun $4(2,48 \%)$ lamanya $\geq 2$ minggu. Keluhan sakit perut berlebihan 85 $(52,80 \%)$. Sebanyak $87(54.04 \%)$ mengalami ketidaknyamanan pada payudara saat menstruasi. Pengeluaran darah menstruasi bercak-bercak 11 (6.83\%) dan darah berlebihan terjadi $45(27.95 \%)$. keputihan 100 (62.11\%). Kondisi keputihan yang telah mengalami perubahan warna terjadi 41 (41 \%). Perubahan emosi sebanyak $133(82.61 \%)$. Saran bagi remaja agar melakukan pencatatan secara rutin riwayat menstruasi dan menjaga kebersihan genetalia selama menstruasi terjadi.
\end{abstract}

Kata kunci : Riwayat, Menstruasi, Remaja, Calon Ibu

\section{Descriptive Study of Young Women's Menstrual History As A Mother-To-Be In Pekalongan Region}

\begin{abstract}
Physiologically, young women will experience menstruation. Menstrual history experienced by adolescents is different and is influenced by various factors. This study aims to determine the menstrual history experienced by young women as prospective mothers from the first menstruation to the end, as an identification of impaired reproductive health. The study used a questionnaire with a total of 161 respondents, accidental sample sampling technique. The results showed that more late adolescents (19-24 years) were 156 people (96.89\%). Of the 156 late adolescents, 61 (39.10\%) were 19 years old. The first menstrual period was 12 years as much as 61 (37.90\%), but there were menarche at 16 years as much as $3(1.86 \%)$ and 17 years old as much as 1 (0.62\%). The most menstrual cycle was 28 days $87(54.04 \%)$ and $74(45.96 \%)$ cycles of 35 days. Teenagers experienced more menstruation which was $<2$ weeks 157 $(97.51 \%)$. However, 4 (2.48\%) were $\geq 2$ weeks. Complaints of excessive abdominal pain 85 (52, 80\%). A total of 87 (54.04\%) experienced breast discomfort during menstruation. Menstrual discharge with 11 spots (6.83\%) and excessive blood flow occurred 45 (27.95\%). 100 (62.11\%) vaginal discharge. There were 41 (41\%) whitish conditions that had undergone a change in color. Emotional changes were $133(82.61 \%)$. Adolescents are advised to regularly record menstrual history and maintain genetic hygiene during menstruation.

Keyword

: History, Menstruation, Teenagers, Prospective Mother
\end{abstract}




\section{Pendahuluan}

Menstruasi merupakan kondisi fisiologis yang dialami oleh wanita yang berlangsung setiap bulan, menandakan bahwa organ-organ reproduksinya berfungsi dengan baik. Mulainya timbul menstruasi menunjukan bahwa seorang wanita telah mulai matang organ reproduksinya. Wanita yang matang organ reproduksinya siap untuk mengalami kehamilan, persalinan dan nifas. Kehamilan, persalinan dan nifas yang sehat perlu dipersiapkan sejak wanita tersebut masih remaja dan mulai timbulnya menstruasi.

Menstruasi yang datang setiap bulan perlu diketahui kondisinya apakah termasuk dalam kondisi normal ataukah ada suatu penyimpangan, mengingat penyimpangan kesehatan terkait menstruasi dapat berakibat berbagai kondisi pada wanita. Sebagai contoh apabila wanita mengalami menstruasi dengan volume darah berlebihan berdampak pada timbulnya anemia. Anemia pada remaja wanita dapat berakibat fatal seperti resiko berbagai penyakit seperti infeksi dan penyakit lainnya.

Wanita yang mengalami menstruasi lama dan banyak dapat menunjukkan adanya kondisi mioma uteri, yaitu tumor pada uterus atau rahim. Miom yang terjadi dapat mendesak berbagai organ yang ada disekitarnya sehingga dapat menimbulkan gangguan seperti gangguan buang air kecil, gangguan buang air besar, gangguan makan dan sebagainya. Wanita yang mengalami siklus menstruasi terlalu pendek kurang dari 21 hari atau terlalu panjang lebih dari 35 hari menunjukkan kondisi tidak normal sehingga dapat berpengaruh pada reproduksinya untuk hamil apabila wanita tersebut telah menikah. Wanita yang mengalami pre menstruasi sindrom seperti nyeri perut yang sangat dapat mengakibatkan gangguan beraktivitas, gangguan istirahat dan sebagainya.

Berbagai permasalahan yang terjadi pada saat menstruasi perlu diidentifikasi agar dapat segera ditindaklanjuti dengan penanganan yang tepat agar kesehatan dan kesejahteraan wanita dapat tercapai, sehingga kehamilan, persalinan dan nifas yang dialami sehat. Mengingat kesehatan wanita di Indonesia ini masih perlu mendapatkan perhatian dan penanganan yang serius baik oleh pemerintah maupun masyarakat, mengingat kesehatan ibu di Indonesia masih tergolong memprihatinkan dilihat dari angka kematian ibu (AKI).

Berdasarkan uraian tersebut dirasa perlu adanya telaah terhadap menstruasi dari riwayat menstruasi remaja melalui suatu penelitian. Telaah menstruasi dari mulai menarche, siklus menstruasi, lama menstruasi, banyaknya darah menstruasi, keluhan selama menstruasi baik keluhan nyeri perut, keluhan ketidaknyamnaan payudara, kondisi emosi selama menstruasi, maupun keputihan yang menyertai menstruasi.

Berbagai penelitian mengenai menstruasi telah banyak dilakukan namun penelitian yang khusus mengupas semua riwayat menstruasi belum banyak dilakukan. Data yang didapat dalam identifikasi semua riwayat menstruasi dapat dijadikan berbagai kajian baik untuk penelitian selanjutnya maupun untuk kegiatan pengabdian masyarakat sebagai tindaklanjutnya. Oleh karena itu peneliti pada penelitian yang telah dilakukan ini merumuskan masalah penelitian bagaimana riwayat menstruasi remaja putri di kabupaten pekalongan. 


\section{Hasil Penelitian}

Penelitian telah dilakukan dengan mengumpulkan remaja putri. Pengambilan sampel dengan teknik accidental sample. Responden penelitian sebanyak 161 remaja putri. Adapun penjabaran usia responden dapat terlihat pada tabel di bawah ini:

1. Distribusi Responden Berdasarkan Usia

Berdasarkan tabel tersebut, remaja putri dalam penelitian ini usia lebih banyak dalam kategori remaja akhir (usia 19-24 tahun) sebanyak 156 orang (96.89\%). Dari 156 remaja akhir, 61 Orang $(39,10 \%)$ berusia 19 tahun.

Tabel: 4.1 Gambaran Menstruasi Remaja Putri Berdasarkan Usia Di Wilayah Kabupaten-Kota Pekalongan Bulan Februari 2020

\begin{tabular}{ccc}
\hline Usia & Frekuensi & Prosentase \\
\hline $\begin{array}{c}\text { Remaja Awal } \\
(12-15)\end{array}$ & 0 & $0 \%$ \\
\hline $\begin{array}{c}\text { Remaja } \\
\text { Pertengahan } \\
(16-18)\end{array}$ & 5 & $3.11 \%$ \\
\hline $\begin{array}{c}\text { Remaja } \\
\text { Akhir }(19-24)\end{array}$ & 156 & $96.89 \%$ \\
\hline Total & $\mathbf{1 6 1}$ & $\mathbf{1 0 0 \%}$ \\
\hline
\end{tabular}

2. Distribusi Responden Berdasarkan Usia Menstruasi Pertama (Menarche)

Berdasarkan table tersebut, remaja putri dalam penelitian ini menstruasi pertama terbanyak pada usia 12 tahun sebanyak 61 Orang $(37.90 \%)$, namun ada pula yang baru menarche pada usia 16 tahun sebanyak 3 Orang $(1.86 \%)$ dan usia 17 tahun sebanyak 1 orang $(0.62 \%)$.
Tabel : 4.2 Gambaran Menstruasi

Remaja Putri Berdasarkan Menarche di Wilayah Kabupaten-Kota Pekalongan Bulan Februari 2020

\begin{tabular}{ccc}
\hline Usia & Frekuensi & Prosentase \\
\hline 11 tahun & 13 & $8.07 \%$ \\
\hline 12 tahun & 61 & $37.90 \%$ \\
\hline 13 tahun & 54 & $33.54 \%$ \\
\hline 14 tahun & 19 & $11.80 \%$ \\
\hline 15 tahun & 10 & $6.21 \%$ \\
\hline 16 tahun & 3 & $1.86 \%$ \\
\hline 17 tahun & 1 & $0.62 \%$ \\
\hline Total & $\mathbf{1 6 1}$ & $\mathbf{1 0 0 \%}$ \\
\hline
\end{tabular}

3. Distribusi Responden Berdasarkan Siklus Menstruasi

Berdasarkan grafik tersebut menunjukkan bahwa remaja dengan siklus menstruasi terbanyak adalah 28 hari sebanyak 87 orang $(54,04 \%)$ dan tergambarkan dalam grafik tersebut sebanyak 74 orang $(45,96 \%)$ mengalami siklus panjang 35 hari. Siklus Menstruasi Remaja dalam penelitian ini dapat tergambar dalam grafik berikut ini.

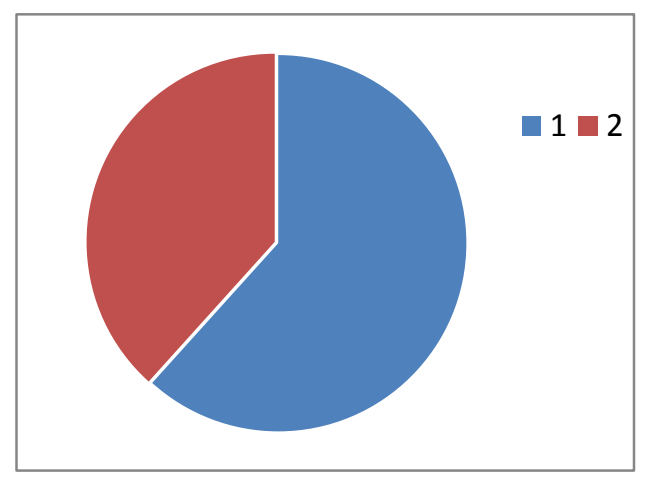


Gafik 4.1. Distribusi Responden Berdasarkan Siklus Menstruasi Remaja Putri Di Wilayah Kabupaten-Kota Bulan Februari 2020

4. Distribusi Responden Berdasarkan Lama Menstruasi

Berdasarkan grafik tersebut dapat dilihat bahwa remaja lebih banyak mengalami menstruasi yang lamanya < 2 minggu sebanyak 157 orang $(97,51 \%)$. Namun ada 4 orang $(2,48 \%)$ mengalami mnstruasi yang lamanya $\geq 2$ minggu. Lama menstruasi remaja dalam penelitian ini dapat tergambarkan dalam grafik berikut ini.

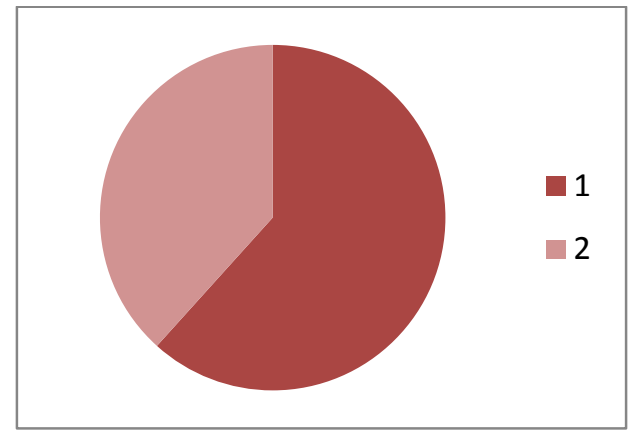

Grafik 4.2 Distribusi Responden Berdasarkan Lama Menstruasi Remaja Putri di Wilayah Kabupaten - Kota Bulan Februari 2020

5. Distribusi Responden Berdasarkan Keluhan Sakit Perut Saat Menstruasi Berdasarkan grafik tersebut menunjukkan remaja mengalami keluhan sakit perut berlebihan sebanyak 85 Orang $(52,80 \%)$ dan 76 Orang $(47,20 \%)$ tidak mengalami sakit perut. Keluhan sakit perut berlebihan pada remaja dalam penelitian ini dapat terlihat dalam grafik berikut ini.

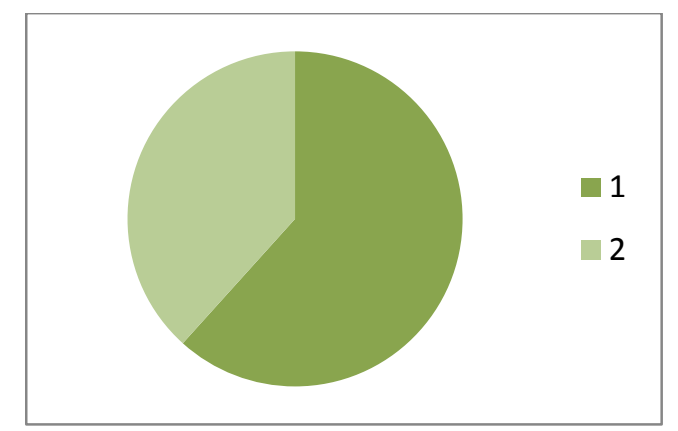

Grafik 4.3 Distribusi Responden

Berdasarkan Keluhan Sakit Perut Saat Menstruasi Pada Remaja Putri Bulan Februari 2020 Di Wilayah KabupatenKota Pekalongan

6. Distribusi Responden Berdasarkan Ketidaknyamanan Pada Payudara Selama Menstruasi

Berdasarkan grafik tersebut menunjukkan bahwa remaja putri dalam penelitian ini sebanyak 87 Orang (54.04 \%) mengalami ketidaknyamanan pada payudara saat menstruasi. Sedangkan 74 Orang (45.96\%) mengalami ketidaknyamanan pada payudara.

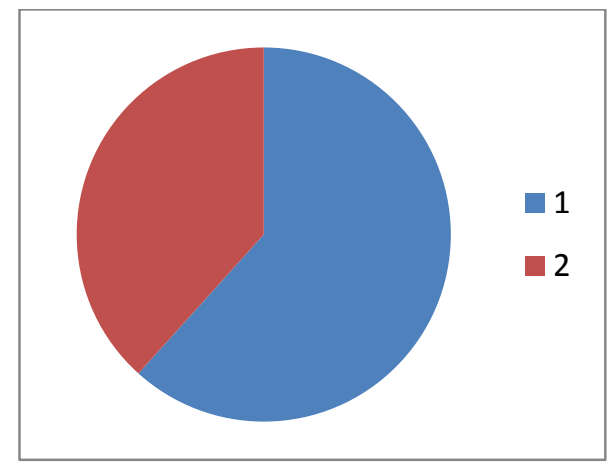

Garfik 4.4 Distribusi Responden Berdasarkan Ketidaknyamanan Pada Payudara Saat Menstruasi Pada Remaja Putri Bulan Fabruari 2020 Wilayah Kabupaten-Kota Pekalongan 
7. Distribusi Responden Berdasarkan Banyaknya Darah Menstruasi

Berdasarkan grafik tersebut menunjukkan bahwa remaja putri dalam penelitian ini lebih banyak mengalami pengeluaran darah tidak terlalu banyak yaitu $105(65.22 \%)$, namun remaja yang pengeluaran pervaginam menstruasi hanya bercakbercak darah sebanyak 11 Orang $(6.83 \%)$ dan darah berlebihan terjadai pada 45 Orang $(27.95 \%)$. Banyaknya darah menstruasi remaja putri pada penelitian ini dapat tergambarkan dalam grafik berikut.

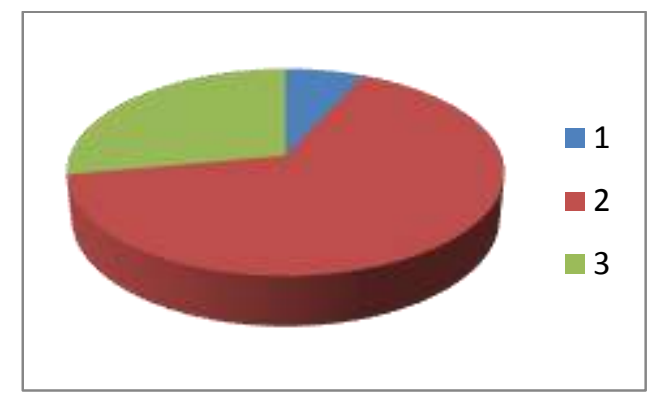

Garfik 4.5 Distribusi Responden Berdasarkan Banyaknya Darah Menstruasi Pada Remaja Putri Bulan Fabruari 2020 Wilayah KabupatenKota Pekalongan

8. Distribusi Responden Berdasarkan Keputihan

Berdasarkan grafik tersebut menunjukkan adanya remaja putri yang mengalami keputihan 100 Orang $(62.11 \%)$ dan 61 Orang $(37.89 \%)$ tidak mengalami keputihan.

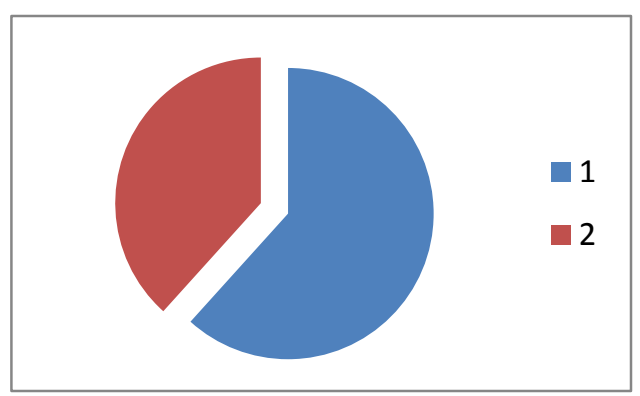

Grafik 4.6 Distribusi Responden Berdasarkan Keputihan Pada Remaja Putri Bulan Februari 2020 Di Wilayah Kabupaten Kota Pekalongan

9. Distribusi Responden Berdasarkan Kondisi Keputihan

Berdasarkan grafik tersebut menunjukkan kondisi keputihan yang telah mengalami perubahan warna terjadi pada 41 Orang $(41 \%)$ dan remaja yang mengalami keputihan namun tidak adanya perubahan warna sebanyak 59 Orang (59\%). Dari 100 remaja putri yang mengalami keputihan, kondisi keputihan yang dialami remaja tersebut tergambar pada grafik berikut ini: 


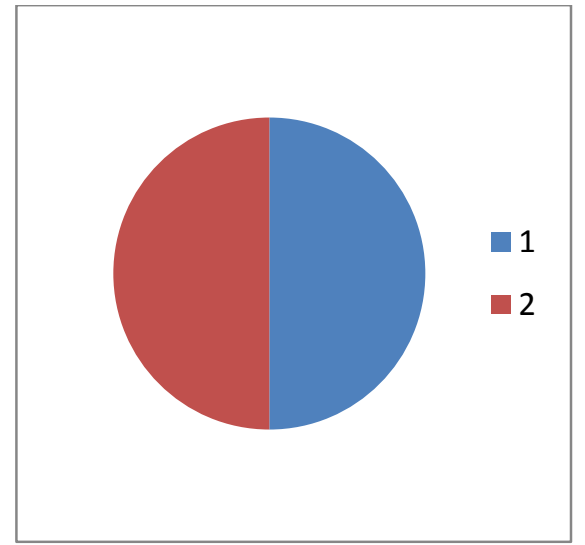

Grafik 4.7 Distribusi Responden

Berdasarkan Kondisi Keputihan Pada Remaja Putri Bulan Februari 2020 Di

Wilayah Kabupaten Kota Pekalongan

10. Distribusi Responden Berdasarkan Perubahan Emosi

Berdasarkan grafik tersebut menunjukkan remaja prutri dalam penelitian ini mengalami perubahan emosi sebanyak 133 Orang (82.61\%) dan terdapat 28 orang $(17.39 \%)$ tidak mengalami perubahan emosi pada saat menstruasi.

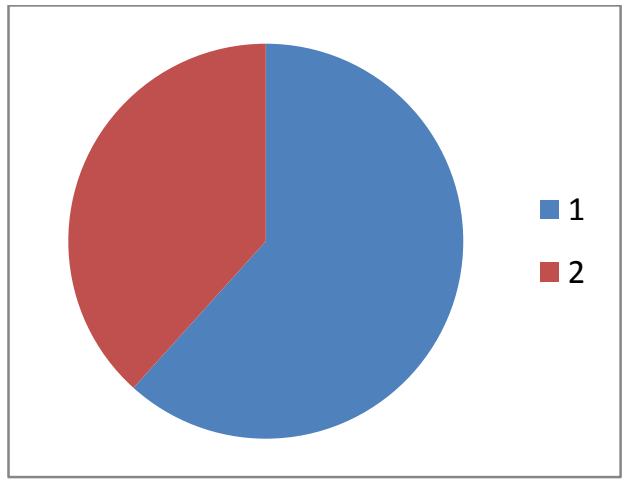

Grafik 4.8 Distribusi Responden

Berdasarkan Perubahan Emosi Pada

Remaja Putri Saat Menstruasi Bulan

Februari 2020 di Wilayah Kabupaten Kota Pekalongan

Pembahasan

1. Distribusi Remaja Putri Berdasarkan Usia

Hasil penelitian ini menunjukkan bahwa usia remaja putri lebih banyak dalam kategori remaja akhir (usia 19-24 tahun) sebanyak 156 Orang (96.89\%). Dari 156 remaja akhir, 61 Orang $(39,10 \%)$ berusia 19 tahun.

Remaja akhir usia 19-24 merupakan masa transisi ke usia dewasa. Remaja putri yang berusia tersebut ada yang telah menikah, hamil dan mempunyai anak. Kehamilan diusia 19 tahun merupakan kehamilan yang beresiko, mengingat alat-alat repoduksi belum matang sehingga tidak jarang menimbulkan kondisi kesakitan dan kematian ibu maupun bayi akibat perdarahan. Usia reproduksi sehat pada wanita adalah usia 20 tahun hingga 35 tahun.

Remaja putri dalam penelitian ini sebagian besar belum menikah, namun hanya ada beberapa remaja putri yang telah menikah. Remaja putri dalam penelitian ini merupakan remaja putri dengan kondisi yang harus dipersiapkan untuk menikah, hamil, dan melahirkan. Oleh karena itu kesehatan repoduksinya perlu diperhatikan, salah satunya dengan memperhatikan riwayat menstruasinya.

Mencatat riwayat menstruasi merupakan salah satu upaya untuk mengidentifikasi kondisi atau riwayat menstruasi normal ataukah adanya penyimpangan. Catatan yang harus dilakukan diantaranya mencatat menstruasi pertama (menarche), siklus menstruasi, banyaknya darah yang keluar, keluhan saat menstruasi.

\section{Distribusi Remaja Putri Berdasarkan} Usia Menarche

Hasil penelitian ini menunjukkan bahwa remaja putri mengalami menstruasi pertama terbanyak pada usia 12 tahun sebanyak 
61 Orang (37.90\%), namun ada pula yang baru menarche pada usia 16 tahun sebanyak 3 Orang $(1.86 \%)$ dan usia 17 tahun sebanyak 1 Orang $(0.62 \%)$.

$$
\text { Hasil penelitian ini }
$$

menunjukkan kondisi normal rata-rata usia menstruasi pertama atau menarche yaitu 12 tahun. Menstruasi rutin pada sebagian besar remaja putri di usia 16 hingga 18 tahun. Menstruasi pertama atau menarche merupakan tanda seseorang remaja putri mulai dinyatakan akhil baliq. Kondisi tersebut menunjukkan bahwa seorang remaja putri mulai berfungsi alat reproduksinya, hormone-hormon diproduksi dengan baik, ovarium \& uterus mulai berfungsi.

Remaja putri yang beragama islam sudah mulai mempunyai kewajiban untuk menjalankan ibadah setelah darah menstruasi berhenti seperti ibadah sholat, ibadah puasa wajib di bulan ramadhan serta ibadah lainnya. Remaja putri yang mulai menstruasi juga sudah mulai diberikan pendidikan kesehatan mengenai kebersihan diri termasuk kebersihan genetalia eksternanya agar terhindar dari penyakit-penyakit infeksi pada genetalia yang dapat berpengaruh pada kesuburan, kehamilan, persalinan maupun nifasnya kelak. Hal ini seperti yang disebutkan pada Al Qur'an Surat Al Baqarah (2): 222 yang artinya sebagai berikut:

"Mereka bertanya kepada mu tentang haids. Katakanlah: haidh itu adalah suatu kotoran, oleh sebab itu hendaklah kamu menjauhkan diri dari wanita di waktu haidh"

Llewellyn-Jones \& Derek (2005) menstruasi merupakan puncak dari serangkaian perubahan yang terjadi pada seorang remaja putri yang sedang menginjak dewasa dan sebagai tanda bahwa remaja putri tersebut sudah mampu untuk hamil.

Pada penelitian ini didapatkan adanya 1 orang $(0,62 \%)$ yang mengalami menarche di usia 17 tahun, remaja putri tersebut saat penelitian berusia 19 tahun, hal ini berarti remaja putri tersebut baru mengalami menstruasi selama dua tahun. Marianti (2018) remaja putri yang belum mengalami menstruasi pertama (Menarche) pada usia 15 tahun merupakan salah satu kelainan pada menstruasi. Wanita yang mengalami kondisi belum menarche pada usia 14 tahun diikuti dengan tanda-tanda HIRSUTISME juga merupakan salah satu kelainan dalam menstruasi. HIRSUTISME adalah pertumbuhan rambut seperti pada laki-laki dibagian wajah, dada, atau punggung akibat kelebihan hormone androgen. Wikjosastro (2008) usia menarche dipengaruhi factor keturunan, keadaan gizi, kesehatan.

Penelitian Yunitasari, dkk (2009) disimpulkan bahwa ada hubungan antara status nutrisi dengan usia menarche, $p=0,001$. Hasil penelitian tersebut berarti kondisi kesehatan seorang wanita yang bagus akibat konsumsi nutrisi yang bagus akan mempengaruhi awal mula datangnya menstruasi. Pada wanita gemuk lebh banyak mengalami menarche pada usia sebelum 13 tahun. Pada penelitian tersebut dinyatakan usia terbanyak menarche yaitu usia lebih dari 13 tahun. Santrock, J.W. (2008) rata-rata menarche wanita 
Indonesia adalah rentang 10 -13 tahun atau usia remaja awal.

3. Distribusi Remaja Putri Berdasarkan Siklus Menstruasi

Hasil penelitian ini menunjukkan bahwa remaja putri dengan siklus menstruasi terbanyak adalah 28 hari sebanyak 87 orang $(54,04 \%)$ dan tergambarkan dalam grafik tersebut sebanyak 74 orang $(45,96 \%)$ mengalami siklus panjang 35 hari.

Siklus menstruasi secara normal dengan siklus 21-35 hari. Siklus kurang dari 21 hari merupakan siklus pendek dan siklus lebih dari 35 hari merupakan siklus panjang. Siklus menstruasi 28 hari dengan kondisi teratur merupakan bekal seorang wanita untuk reproduksi sehat termasuk mengatur kehamilan dengan KB kalender.

Penelitian Kristianti dkk (2013) kondisi anemia pada remaja putri berhubungan signifikan dengan siklus menstruasi $p$ value $=0,018$. Pada penelitian tersebut kondisi kadar haemoglobin kurang dari 11,5 \%. Pada kondisi anemia kadar haemoglobin dihitung dari eritrosit yang lebih rendah keadaan normal. Pada penelitian tersebut didapatkan data remaja putri dengan anemia sebanyak $40 \%$ dan mengalami siklus menstruasi tidak normal sebanyak $60 \%$. Remaja putri tidak semua menyukai makanan yang mengandung vitamin B12 atau makanan yang banyak mengandung zat besi. Wahyuningsih \& Astuti (2011) menyatakan pula adanya hubungan yang signifikan antara anemia dengan keteraturan siklus menstruasi, $p=0,001$. Penelitian Dyah, N.M \& Adiningsih,S. (2019) menyimpulkan adanya hubungan antara status gizi dengan siklus menstruasi $p$ value $=0,036$. Responden dengan status gizi normal sebanyak $66,3 \%$ sebagian besar memiliki siklus menstruasi normal $62,7 \%$. Responden yang mengalami obesitas siklus mentruasi tidak normal $71,4 \%$.

Gangguan siklus menstruasi berupa oligomenorche lebih banyak terjadi pada wanita yang obesitas $30,8 \%$. Wanita yang obesitas $1,89 \mathrm{kali}$ lebih besar mengalami gangguan siklus menstruasi dibandingkan dengan wanita yang tidak mengalami obesitas (Rakhmawati \& Dieny, 2012). Pada penelitian tersebut disampaikan bahwa gangguan menstruasi merupakan penyebab utama infertilitas pada wanita (Kocelak, 2012 dalam Rakhmawati \& Dieny, 2012). Oligomenorche adalah kondisi wanita yang mengalami siklus menstruasi panjang lebih dari 35 hari bahkan setelah 90 hari. Siklus menstruasi yang panjangnya melebihi 3 bulan bukan lagi dinamakan oligomenorche namun sudah dikategorikan amenorche. Oligomenorche disebabkan beberapa factor diantaranya gangguan pola makan, penyakit diabetes mellitus, penyakit tiroid, dapat pula disebabkan penggunaan kontrasepsi, penggunaan obat penunda menstruasi, serta olah raga berat (American College Of Obstetrician and Gynecologists (2015).

$$
\text { Kondisi menstruasi }
$$
dipengaruhi berbagai factor. Adapun factor yang mempengaruhi menstruasi diantanya factor nutrisi. Marmi (2013) wanita dengan gizi lebih maka jumlah hormone estrogen dalam darah meningkat akibat meningkatnya jumlah lemak tubuh. Kadar estrogen tinggi berdampak negative terhadap 
sekresi hormone GnRH, yang dapat menghambat hipofisis antaerior untuk menstimulasi FSH. Hambatan sekresi FSH menyebabkan gangguan pertumbuhan folikel sehingga folikel yang matang tidak terbentuk. Dampak kondisi tersebut adalah panjangnya siklus menstruasi atau keterlambatan menstruasi.

Wanita dengan status gizi yang kurang menyebabkan penurunan gonadotropin. Fungsi gonadotropin untuk pengeluaran LH dan FSH. Bila kondisi tersebut terjadi maka estrogen akan turun sehingga terjadi gangguan siklus menstruasi dan ovulasi (Marmi, 2013).

Penelitian Hidayah, Rahfiludin \& Aruben (2016) didapatkan 50\% remaja putri dengan status gizi baik, yang berarti $50 \%$ nya dengan status gizi kurang baik. Pada penelitian tersebut didapatkan $69,4 \%$ remaja putri dengan asupan protein sedikit, 81,5\% sedikit asupan lemak, 74,1\% sedikit asupan sumber energy, 88,9\% sedikit kalsium. Pada penelitian tersebut juga didapatkan hasil $60,2 \%$ remaja putri dengan siklus menstruasi tidak teratur. Kesimpulan dari seluruh penelitian Hidayah,dkk (2016) tersebut bahwa ada hubungan status nutrisi dengan siklus menstruasi $p$ value < 0,005. Pada penelitian tersebut secara rinci dijabarkan adanya hubungan asupan protein dengan siklus menstruasi $p=0,001$. Remaja tersebut dengan asupan protein kurang dan mengalami siklus tidak nteratur sebanyak 49,1\%. Selain itu ada hubungan asupan lemak dengan siklus menstruasi $p=0,001$, remaja dalam penelitian tersebut asupan lemak kurang dan mengalami menstruasi tidak teratur sebanyak $55,6 \%$.

Asupan protein yang kurang akan mempengaruhi penurunan frekuensi puncak LH dan akan mengalami npemendekan fase folikuler. Wanita vegetarian yang diet protein hewani terjadi fase folikuler memanjang dan FSH meningkat.

Asupan lemak yang kurang berdampak paa penurunan fungsi reproduksi. Lemak mempengaruhi kadar gonadotropin dalam serum. Penerunan gonagotropin mengganggu fungsi hipotalamus. FSH, LH, Estrogen, Progesteron menjadi terganggu, pada akhirnya tidak dapat dihasilkannya sel telur yang matang sehingga siklus menstruasi terlalu lama (Manuaba, 2010).

Berdasarkan konsep dan hasilhasil penelitian tersebut disimpulkan bahwa nutrisi yang dikonsumsi seorang wanita berpengaruh terhadap menstruasi yang dialaminya. Nutrisi yang dikonsumsi menjadi bekal untuk alat-alat reproduksi berfungsi dengan baik. Kondisi anemia pada remaja putri dimana kadar haemoglobin kurang dari $12 \mathrm{~g} / \mathrm{dl}$ akan berdampak pada menstruasi yang dialami remaja putri tersebut

4. Distribusi Remaja Putri Berdasarkan Lama Menstruasi

Hasil penelitian ini menunjukkan bahwa remaja putri lebih banyak mengalami menstruasi yang lamanya $<2$ minggu sebanyak 157 orang $(97,51 \%)$. Namun ada 4 orang $(2,48 \%)$ mengalami mnstruasi yang lamanya $\geq 2$ minggu.

Pada sebagian besar wanita lama menstruasi adalah 3-7 hari (Marianti, 2018). Menstruasi lebih dari 
7 hari dengan volume darah berlebihan disebut menorrhagia, disebabkan ketidakseimbangan hormone atau dapat juga disebabkan adanya miom. Wanita yang mengalami lama menstruasi lebih dari 2 minggu dalam agama islam wanita tersebut tetap mempunyai kewajiban menjalankan ibadah wajib seperti sholat dan puasa di bulan ramadhan diganti puasa dibulan lainnya mengingat lama menstruasi lebih dari 2 minggu diduga adanya penyakit yang berhubungan dengan alat reproduksi wanita tersebut seperti tumor ataupun kanker leher Rahim yang ditandai salah satunya adalah keluarnya darah yang banyak dan dalam waktu yang lama. Oleh karena itu remaja putri perlu mencatat kapan mulai menstruasi dan kapan berakhir menstruasi serta banyaknya menstruasi untuk mengidentifikasi adanya penyimpangan atau kondisi penyakit yang berhubungan dengan alat reproduksinya.

5. Distribusi Remaja Putri Berdasarkan Keluhan Nyeri Perut Saat Menstruasi Hasil penelitian ini menunjukkan remaja putri mengalami keluhan sakit perut berlebihan saat menstruasi sebanyak 85 Orang (52, $80 \%)$ dan 76 Orang $(47,20 \%)$ tidak mengalami sakit perut.

Kondisi sakit perut atau nyeri dapat dialami dalam skala ringan sampai skala berat. Nyeri berat yang dialami remaja putri saat menstruasi dapat terjadi pada awal usia mulai menstruasi (menarche) sampai 3 tahun menstruasi. Kondisi tersebut dinamakan dismenorche primer. Namun ada pula nyeri menstruasi dialami setelah bertahun tahun menstruasi, hal tersebut dinamakan dismenorche sekunder.

Penelitian Putrie, H.C. (2014) riwayat keluarga berhubungan dismenorche, $p=0,001$. Berdasarkan hasil penelitian tersebut menunjukkan bahwa ibu yang mengalami dismenorche mempunyai resiko anak perempuannya mengalami dismenorche pada saat menstruasinya. Hasil penelitian Putrie, H.C. (2014) juga menyatakan bahwa lama menstruasi berhubungan dengan kondisi dismenorche, $p=0,0279$.

Rasa sakit yang dialami remaja putri pada siklus haid biasanya terjadi pada sebelum menstruasi, selama menstruasi, hingga berakhir siklus menstruasi. Penyebab dismenorche beragam diantaranya akibat factor endokrin sampai factor psikologis. Adapun pencetus dismenorche diantaranya adalah usia dini saat menstruasi kurang dari 12 tahun, perdarahan menstruasi yang hebat, riwayat keluarga dengan dismenorche, adanya gangguan endometriosis dan masih banyak factor pencetus lainnya (Ratnawati, A. 2018).

Endometriosis merupakan suatu kelainan dimana endometrium yang biasa tumbuh didalam uterus, pada kondisi tersebut tumbuh di luar uterus. Wanita yang mengalami endometriosis biasanya mengalami nyeri yang luar biasa saat siklus menstruasi. Efek dari endometriosis pada wanita tersebut adalah kemandulan dan kehamilan ektopik. Endometriosis bersifat herediter, insiden lebih tinggi pada wanita yang ibunya mengalami endometriosis (Ratnawati, A. 2018).

Rasa nyeri atau sakit dismenorche menurut derajatnya mulai 
dari nyeri berlangsung hanya beberapa saat saja sampai derajat tiga yaitu nyeri dismenorche yang luar biasa hingga membutuhkan waktu untuk istirahat beberapa hari. Wanita dengan dismenorche dapat mengalami pingsan, gangguan metabolisme hingga menyebabkan diare, sakit pinggang, dan paha bagian dalam (Ratnawati, A. 2018).

6. Distribusi Remaja Putri Berdasarkan Keluhan Ketidaknyamanan Payudara Payudara remaja putri pertumbuhannya pada stadium 2 atau disebut breast bud merupakan suatu tanda pubertas pertama. Breast bud terdiri dari penonjolan putting disertai pembesaran daerah areola pada sekitar 8-12 tahun. Pada usia 12 tahun remaja putri mengalami pacu tumbuh dimana payudara \& areola mamae membesar, batas tidak jelas. Pada usia 13 tahun remaja putri mengalami kecepatan tumbuh melambat, areola dan papilla membentuk bukit kedua. Pada usia 1415 tahun remaja putri mengalami pertumbuhan minimal, payudara areola tidak menonjol (Soetjiningsih, 2004).

Hasil penelitian ini menunjukkan bahwa remaja putri sebanyak 87 Orang (54.04 \%) mengalami ketidaknyamanan pada payudara saat menstruasi. Sedangkan $74 \quad$ Orang $(45.96 \%)$ mengalami ketidaknyamanan pada payudara. Pada wanita yang mengalami menstruasi payudara menjadi sensitive (Marianti, 2018). Nyeri dan pembesaran payudara sebelum menstruasi dinamakan Mastalgia, disebabkan edema dan hiperemi akibat peningkatan relative kadar estrogen (Wikjosastro, 2008).
Ketidaknyamanan payudara yaitu payudara terasa membengkak, payudara menjadi sensitive merupakan salah satu tanda gejala pre menstrual sindrom (PMS). Penyebab PMS belum dapat diketahui dengan pasti. Beberapa ahli mengatakan PMS dipengaruhi oleh ketidakstabilan hormone progesterone dan estrogen yang ada pada system reproduksinya, dan permasalahan.

7. Distribusi Remaja Putri Berdasarkan Banyaknya Darah Saat Menstruasi

Hasil penelitian menunjukkan bahwa remaja putri dalam penelitian ini lebih banyak mengalami pengeluaran darah tidak terlalu banyak yaitu 105 orang $(65.22 \%)$, namun remaja yang pengeluaran pervaginam menstruasi hanya bercak-bercak darah sebanyak 11 Orang (6.83\%) dan darah berlebihan terjadi pada 45 Orang $(27.95 \%)$.

8. Distribusi Remaja Putri Berdasarkan Pengeluaran Flor albus (Keputihan)

Hasil penelitian ini menunjukkan adanya remaja putri yang mengalami keputihan 100 Orang $(62.11 \%)$ dan 61 Orang $(37.89 \%)$ tidak mengalami keputihan.

9. Distribusi Remaja Putri Berdasarkan Kondisi Keputihan

$\begin{array}{ccr}\text { Hasil } & \text { penelitian } & \text { ini } \\ \text { menunjukkan } & \text { remaja putri yang }\end{array}$ mengalami kondisi keputihan yang telah berubah warna terjadi pada 41 Orang $(41 \%)$ dan remaja yang mengalami keputihan namun tidak adanya perubahan warna sebanyak 59 Orang (59\%).

Keputihan encer sampai kental, warna keputihan menjadi kekuningan, gatal, rasa panas seperti terbakar, berbau adalah tanda gejala adanya vaginitis. Vaginitis adalah penyakit 
radang vagina yang ditandai dengan keluarnya cairan keputihan sampai berubah warna dan disertai tanda gejala keputihan encer sampai kental, warna keputihan menjadi kekuningan, gatal, rasa panas seperti terbakar, berbau. Etiologi penyakit vaginitis adalah akibat bakteri, parasite dan jamur (Ratnawati, A. 2018).

Pada area vagina terdapat $\mathrm{pH}$ asam yang dapat melindunginya dari serangan bakteri, jamur, dan menjauhkan vagina dari infeksi. Namun pada beberapa kasus $\mathrm{pH}$ mengalami perubahan sehingga bakteri atau jamur dapat masuk dan merusak jaringan yang ada pada vagina hingga menyebabkan infeksi pada vagina. Perubahan pH biasanya terjadi pada kasus stress, alergi dermatologis, estrogen yang rendah, kehamilan, dampak dari pemakaian kontrasepsi vagina atau dari kontrasepsi oral, serta celana yang ketat, tidak berbahan katun yang dapat menyerap keringat (Ratnawati, A. 2018).

$$
\text { Ratnawati, A. }
$$

Penanganan kondisi vaginitis adalah menjaga kebersihan area genetalia, kebersihan pakaian dalam, celana dalam tidak terlalu ketat. Hasil penelitian ini menunjukkan remaja putri yang mengalami kondisi keputihan yang telah berubah warna terjadi pada 41 Orang (41 \%) yang artinya hamper separuh remaja putri tersebut kemungkinan mengalami infeksi pada vagina yang disebabkan berbagai factor yang diduga diantaranya kebersihan genetalia kurang dijaga, celana dalam yang terlalu ketat, celana dalam tidak berbahan katun yang menyerap keringat.

\section{Distribusi Remaja Putri Berdasarkan Perubahan Emosi Saat Menstruasi} Hasil penelitian ini menunjukkan remaja putri mengalami perubahan emosi sebanyak 133 Orang $(82.61 \%)$ dan terdapat 28 Orang $(17.39 \%)$ tidak mengalami perubahan emosi pada saat menstruasi.

\section{Daftar Pustaka}

American College of Obstetrician and Gynecologists. 2015. Menstruation In Gilrls And Adolescents: Using The Menstrual Cycle as a vital Sign.

Asrawati . 2010. Gambaran Pengetahuan

Remaja Putri Tentang Menstruasi di SMP N 3 Sunggu Minahasa

Kabupaten Gowa

Davis, J.B. Segar, J.H. 2009.

Menstruation And Menstrual

Disorders: An Ovulation.

Glob.Libr. Women's Med

Deligeoroglou E, Tsimaris P, Deliveliotou

A. Menstrual 5. disorders during adolescence. Pediatr Endocrino 2009;3(1):150-9.

Dieny. 2014. Permasalahan Gizi Pada Remaja Putri. Yogyakarta: 1. Graha Ilmu

Gudmundsdottir SL, Flanders WD, Augestad LBA. 6. Longitudinal study of physical activity and menstrual cycle characteristics in healthy norwegian women - the nord-trøndelag health study. Norsk Epidemiologi 2011;20(2):163-71

Hidayah, N., Rahfiludin, M.Z., Aruben, R. 2016. Hubungan Status Gizi, Asupan Zat Gizi, dan Akativitas Fisik dengan Siklus Menstruasi Remaja Putri Pondok Pesantren Salafiyah Kauman Kabupaten Pemalang. Journal Kesehatan 
Masyarakat (e-journal) Vol 4. No.4

Oktober 2016. ISSN: 2356-3346.

http://ejournal-

Sl.undip.ac.id/index.php/jkm

Indriyani, D. 2013. Keperawatan

Maternitas. Cetakan Pertama.

Graha Ilmu. Yogyakarta

Krstianti, S., Wibowo, T.A,. Winarsih, 2014. Hubungan Anemia Dengan

Siklus Menstruasi Pada Remaja

Putri di SMA Negeri I Imofiri,

Bantul Yogyakarta. Jurnal Studi

Pemuda, Vol.3 No.1.Mei 2014.

http://C/User/appdata/Local/temp/

32036-75161-1-PB.pdf

Llewellyn-jones, Derek. 2005. Setiap

Wanita. Jakarta: PT. Delapratasa

Publishing, EGC.

Lowdermilk. At.all. 2013. Maternity

Nursing. $8^{\text {th }}$ Edition. Arrangment with Elsevier Inc. Alih Bahasa : Sidartha, S \& Tania A. Buku Keperawatan Maternitas. 2013. Elsevier Mosby. Singapore

Marmi. 2013. Gizi dalam Kesehatan

Reproduksi. Yogyakarta: Pustaka Pelajar.

Putrie, H.C. 2014. Hubungan Antara Tingkat Pengetahuan, Usia Menarche, Lama Menstruasi \& Riwayat Keluarga dengan Kejadian Dismenorche.

Rahmawati, A. \& Dieny, F.F.2012.

Hubungan Obesitas Dengan

Kejadian Gangguan Siklus

Menstruasi Pada Wanita Dewasa

Muda

Santrock, John W. (2003), Adolescence Perkembangan Remaja, trans. Shinto B. Adelar; Sherly Saragih, Jakarta, Erlangga.

Sitoayu, L., Pertiwi, D.A., Mulyani, E.Y. 2017. Kecukupan Zat Gizi Makro,
Status Gizi, Stress, dan Siklus Menstruasi Remaja. Journal Gizi Klinik Indonesia. Vol.13 No.3 Januari 2017 (121-128). ISSN 1693900x (Print), ISSN 2502-4140 (online).

http://journal.ugm.ac.id/jgki

Wahyuningsih, A. \& Astuti, S.P. 2011.

Hubungan Kadar Hemoglobin

Dengan Keteraturan Siklus

Menstruasi Pada Mahasiswi Prodi

D III Kebidanan Tingkat III

STIKES Muhammadiyah Klaten

Yunitasari, E., Indarwati, R., Sofia, D.R.2009. Status Gizi

Mempengaruhi Usia Menarche. Journal Ners. Vol.4 No.2: 168-175.

Yulia Wahyuni, Ratna Dewi 2018; Jurnal

Gizi Indonesia (The Indonesian Journal of Nutrition), 6 (2), 2018 eISSN : 2338-3119, p-ISSN: 1858-

4942 Gangguan siklus menstruasi kaitannya dengan asupan zat gizi pada remaja vegetarian

Wikjosastro, H. 2008. Ilmu Kebidanan.

Penerbit: Yayasan Bina Pustaka Sarwono Prawiroharjo. Jakarta 